\title{
TEKNOLOGI PENGOLAHAN LAHAN BASAH BUATAN UNTUK MENGOLAH GREY WATER DARI RUMAH TANGGA
}

\author{
Novita Rosiana Dewi \\ Jurusan Teknik Lingkungan, Fakultas Arsitektur Lanskap dan Teknologi Lingkungan, \\ Universitas Trisakti, Jakarta, Indonesia
}

Email korespondensi: novita08215042@trisakti.ac.id

\begin{abstract}
ABSTRAK
Pertumbuhan penduduk Indonesia diperkirakan akan terus betambah pesat seiring berjalannya waktu. Pertumbuhan penduduk tersebut akan menyebabkan produksi air limbah domestik dari permukiman semakin meningkat. Terdapat berbagai efek buruk yang dihasilkan dari pencemaran air limbah domestik yang tidak dikelola dengan baik. Air limbah domestik jenis grey water merupakan jenis yang biasanya langsung dibuang ke badan air sungai. Oleh karena itu, produksi air limbah domestik harus diminimalkan dengan pemilihan dan penerapan teknologi pemrosesan yang sederhana, mudah dan murah dalam pengoperasian dan pemeliharaannya. Salah satu teknologi untuk pengolahan air limbah domestik adalah menggunakan lahan basah buatan. Lahan basah buatan memiliki beberapa sistem yang dapat digunakan. Lahan basah buatan juga bekerja dengan baik menggunakan berbagai jenis tanaman.
\end{abstract}

Kata Kunci: lahan basah buatan; air limbah domestik

\section{PENDAHULUAN}

Pertumbuhan penduduk Indonesia diperkirakan akan terus betambah pesat seiring berjalannya waktu. Pertumbuhan penduduk tersebut akan menyebabkan produksi air limbah domestik dari permukiman semakin meningkat. Air limbah domestik adalah air yang telah dipergunakan dan berasal dari rumah tangga atau pemukiman termasuk di dalamnya adalah yang berasal dari kamar mandi, tempat cuci, WC, serta tempat memasak (Sugiharto, 2008). Air limbah domestik terbagi menjadi dua jenis yaitu black water dan grey water. Black water merupakan air limbah yang berasal dari toilet khususnya dari kotoran manusia berupa tinja sedangkan grey water adalah limbah dari kegiatan domestik selain tinja. Eriksson et al. (2002) dan Yazid et al. (2012) menyatakan bahwa air limbah yang berasal dari air bekas mencuci dan dapur baik di rumah tangga, sekolah maupun perkantoran disebut sebagai limbah grey water. Supradata (2005) menyatakan bahwa 60-70\% air yang digunakan seharihari dibuang langsung ke lingkungan tanpa adanya pengolahan terlebih dahulu. Pembuangan air limbah domestik secara langsung tanpa adanya pengolahan terlebih dahulu dapat mengakibatkan pencemaran air.

Efek buruk dari air limbah yang tidak dikelola dengan baik diantaranya adalah membahayakan kesehatan manusia, dapat menimbulkan kerusakan benda atau bangunan, dan merusak keindahan (estetika) karena bau busuk. Oleh karena itu, hal tersebut harus diminimalisir dengan pemilihan dan penerapan teknologi pengolahan air limbah domestik yang sederhana, mudah, dan murah dalam sistem pengoperasian dan perawatannya.

Salah satu teknologi untuk mengolah air limbah domestik adalah lahan basah buatan. Pada umumnya, lahan basah buatan bekerja optimal dengan memanfaatkan tanaman air. Pemanfaatan tanaman air selain dapat mengolah kandungan pencemar, juga menjadi salah satu upaya untuk mengoptimalkan kebutuhan lahan agar dapat dimanfaatkan menjadi taman. 
Tujuan dari penulisan karya ilmiah ini adalah untuk mengetahui efesiensi lahan basah buatan dalam mengurangi beberapa konsentrasi pencemar pada air limbah domestik.

\section{TINJAUAN PUSTAKA}

\section{Air Limbah Domestik}

Air limbah menurut Peraturan Pemerintah RI Nomor 82 Tahun 2001 tentang Pengelolaan Kualitas Air dan Pengendalian Pencemaran Air adalah sisa dari suatu usaha dan atau kegiatan yang berwujud cair. Air limbah domestik menurut Peraturan Menteri Lingkungan Hidup dan Kehutanan Nomor 68 Tahun 2016 tentang Baku Mutu Air Limbah Domestik adalah air limbah yang berasal dari aktivitas hidup sehari-hari manusia yang berhubungan dengan pemakaian air.

Menurut Fachrizal (2004) selain merusak lingkungan bagian yang paling berbahaya dari limbah domestik yaitu mikroorganisme patogen yang berada dalam tinja manusia, karena dapat menularkan beragam penyakit apabila masuk ke tubuh manusia. Maka untuk mencegah dan mengatasi masalah pencemaran air di badan air, maka dibuat standar baku mutu air limbah. Baku mutu air limbah merupakan ukuran batas atau kadar unsur pencemar dan atau jumlah unsur pencemar yang ditenggang keberedaannya dalam air limbah yang akan dibuang atau dilepas ke dalam sumber air dari suatu usaha dan atau kegiatan. Upaya yang dilakukan pemerintah untuk menahan laju beban pencemaran adalah dengan memberlakukan peraturan terbaru baku mutu air limbah domestik yaitu Peraturan Menteri Lingkungan Hidup dan Kehutanan Nomor P.68/Menlhk/Setjen/Kum.1/8/2016 Tahun 2016 tentang Baku Mutu Air Limbah Domestik. Berikut merupakan data baku mutu air limbah:

Tabel 1. Baku Mutu Air Limbah

\begin{tabular}{ccc}
\hline Parameter & Satuan & Kadar Maksimum* $^{*}$ \\
\hline $\mathrm{pH}$ & - & $6-9$ \\
$\mathrm{BOD}$ & $\mathrm{mg} / \mathrm{L}$ & 30 \\
$\mathrm{COD}$ & $\mathrm{mg} / \mathrm{L}$ & 100 \\
TSS & $\mathrm{mg} / \mathrm{L}$ & 30 \\
Minyak \& Lemak & $\mathrm{mg} / \mathrm{L}$ & 5 \\
Amoniak & $\mathrm{mg} / \mathrm{L}$ & 10 \\
Total Coliform & Jumlah/100mL & 3000 \\
Debit & L/orang/hari & 100 \\
\hline
\end{tabular}

Keterangan: *= Penginapan, rumah susun, asrama, lembaga pendidikan, layanan kesehatan, perkantoran, pasar, rumah makan, balai pertemuan, arena rekreasi, permukiman, industri, IPAL kawasan, IPAL permukiman, IPAL perkotaan, pelabuhan, bandara, stasiun kereta api, terminal dan lembaga permasyarakatan.

Grey water adalah air buangan yang berasal dari sink dapur, wastafel dan floor drain kamar mandi. Air buangan ini termasuk air kotor tetapi bukan berasal dari kotoran manusia. Grey water hanya mengandung 10\% kadar nitrogen dibanding black water. Disamping itu, limbah jenis ini hanya sedikit mengandung bakteri patogen yang merugikan. Sekitar $60 \%$ air buangan rumah tangga merupakan grey water yang berpotensi besar dalam penghematan air jika air tersebut dapat digunakan kembali.

Ariani (2010) menyatakan bahwa daerah yang letaknya tidak berada di pinggir sungai dan walaupun letaknya jauh dari sungai, tetap dapat menjadi sumber pencemar. Hal ini 
dikarenakan beban buangan air tersebut mengalir melalui anak sungai yang akhirnya akan bermuara ke sungai. Hasil yang didapatkan dari perhitungan beban pencemar domestik yang dihasilkan dari penduduk daerah sepanjang DAS sungai Ciliwung segmen 4 paling rendah sebesar $27 \mathrm{mg} / \mathrm{L}$ dan yang tertinggi mencapai 72,16 mg/L. Hal tersebut menunjukan bahwa hasil tersebut melebihi batas baku mutu yang sudah ditetapkan dalam PP No. 82 Tahun 2001 tentang Pengelolaan Kualitas Air.

Conchita (2018) menemukan bahwa konsentrasi rata-rata fosfat di Sungai Ciliwung berada pada kisaran 1,03 mg / 1 - 10,87 mg / 1. Sementara Satmoko (2018) menyatakan bahwa konsentrasi amoniak di Sungai Ciliwung berada pada kisaran 0,02 mg / 1 - 0,4 mg / 1 .

Menurut Vandith (2018) rata-rata rasio BOD/COD dalam air limbah domestik grey water yang ditemukannya sebesar 0,2 di daerah Bandung dan nilai tersebut lebih kecil dari nilai yang terkandung dalam air limbah domestik yang ditemukan oleh Palmaquist dan Hanaux (2005) dan memiliki konsentrasi total suspended solid (TSS) yang rendah, hal tersebut mengidikasikan bahwa kontaminan yang larut lebih banyak. Jefferson et al. (1999) menyatakan bahwa komposisi COD dari grey water rata-rata sebesar 40-371 mg/L. Besar atau kecil komposisi COD pada air limbah domestik tergantung pada berbagai jenis deterjen yang digunakan selama pencucian.

Tabel 2. Kadar Grey Water

\begin{tabular}{ccc}
\hline Parameter & Satuan & Kadar \\
\hline BOD & $\mathrm{mg} / \mathrm{L}$ & $350-500$ \\
COD & $\mathrm{mg} / \mathrm{L}$ & $495-682$ \\
TSS & $\mathrm{mg} / \mathrm{L}$ & $570-700$ \\
TN & $\mathrm{mg} / \mathrm{L}$ & $8-11$ \\
TP & $\mathrm{mg} / \mathrm{L}$ & $4,6-11$ \\
$\mathrm{pH}$ & - & $6,06-8,38$ \\
\hline
\end{tabular}

\section{Lahan Basah Buatan}

Lahan basah buatan merupakan sistem yang digunakan untuk mengolah limbah pemukiman, perkotaan,industri dan pertanian. Lahan basah buatan adalah sistem pengolahan terencana atau terkontrol yang telah didesain dan dibangun menggunakan proses alami yang melibatkan vegetasi, media, dan mikroorganisme untuk mengolah air limbah (Vymazal, 2010). Lahan basah buatan diketahui mempunyai beberapa manfaat seperti pengolahan yang efektif dan bangunan yang kokoh, hemat energi, biaya lebih murah dibandingkan dengan sistem konvensional, memberikan nilai estetika, komersial dan dapat berfungsi sebagai habitat kehidupan liar dengan berkembangnya flora dan fauna yang dapat beradaptasi (Kent, 2001).

Sistem lahan basah buatan yang dikembangkan saat ini yaitu Free Water System (FWS) dan Sub-surface Flow System (SSF). Free Water System (FWS) merupakan sistem dengan aliran di atas permukaan tanah. Sub-surface Flow System (SSF) merupakan sistem dengan aliran di bawah permukaan tanah. Air limbah yang melewati lahan basah buatan mengalir melalui tanaman yang ditanam pada media yang berpori. secara ekonomis, konsep FWS baik untuk diterapkan pada pemukiman skala besar dan sistem industri. Namun secara konsep SSF baik bila diterapkan pada skala yang kecil seperti perumahan individual, komunal, taman, sekolah dan fasilitas publik serta area komrsial. Karena pengaliran air di bawah permukaan batuan, larva dan nyamuk tidak dapat berkembang biak (Metcalf \& Eddy, 1991, Crites dan Tchobanoglous, 1998).

Kriteria umum untuk menentukan spesies tumbuhan lahan basah yang cocok untuk 
pengolahan limbah belum ada, karena sistem yang berbeda memiliki tujuan dan standar yang berbeda. Hal yang patut dipertimbangkan dalam pemilihan tanaman adalah toleran terhadap limbah, mampu mengolah limbah, dan pengaruhnya terhadap lingkungan. Untuk mengetahui tingkat toleransi tanaman terhadap limbah maka perlu diketahui konsentrasi nutrisi dalam limbah. Tumbuhan timbul dan tumbuhan mengapung lebih banyak dipilih untuk digunakan dalam studi lahan basah buatan skala laboratorium.

Tabel 3. Penelitian yang Berkaitan dengan Penulisan Karya Ilmiah

\begin{tabular}{|c|c|c|c|}
\hline No & Penulis & Tahun & Hasil \\
\hline 1. & Abdulgani $\mathrm{H}$, dkk & 2013 & $\begin{array}{l}\text { Typha angustifolia merupakan tanaman yang } \\
\text { mampu menyerap bahan organik dan telah } \\
\text { digunakan dalam teknologi lahan basah karena } \\
\text { tanaman ini mampu mengurangi kekeruhan } \\
\text { (TSS) hingga } 79,9 \% \text {. }\end{array}$ \\
\hline 2. & $\begin{array}{l}\text { Winursita } \mathrm{H} \text { dan } \\
\text { Mangkoedihardjo } \\
\text { S }\end{array}$ & 2013 & $\begin{array}{l}\text { Canna indica merupakan tanaman yang hidup } \\
\text { di dataran rendah hingga ketinggian } 1000 \mathrm{~m} \text { di } \\
\text { atas permukaan laut. Tanaman ini tumbuh besar } \\
\text { dan tegak dengan ketinggian mencapai } 2 \mathrm{~m} \text {. } \\
\text { Daunnya besar dan lebar dan menyirip bening, } \\
\text { hijau atau merah. Hal ini membuat tanaman } \\
\text { Canna indica dapat meningkatkan nilai estetika } \\
\text { lingkungan. }\end{array}$ \\
\hline 3. & Meutia, A. & 2002 & $\begin{array}{l}\text { Tanaman Thypa sp, Pomae } s p \text {, dan Eichornia } \\
s p \text {, di kolam buatan yang dikeringkan dengan } \\
\text { air limbah rumah tangga mampu menurunkan } \\
81 \% \text { kadar amoniak. }\end{array}$ \\
\hline 4. & $\begin{array}{l}\text { Brahmana, S. S } \\
\text { dan Armaita, S }\end{array}$ & 2002 & $\begin{array}{l}\text { Tanaman Thypa sp dan Carex sp mampu } \\
\text { mengurangi kadar amoniak limbah domestik } \\
\text { dalam barisan } 94.00 \% \text { dan } 96.30 \% \text {, dalam } \\
\text { waktu } 18 \text { hari pengamatan. }\end{array}$ \\
\hline 5. & Suriawiria, U & 2003 & $\begin{array}{l}\text { Mikroorganisme dalam akar tanaman mampu } \\
\text { menguraikan bahan organik dan anorganik } \\
\text { menjadi senyawa yang lebih sederhana. } \\
\text { Pengurangan kadar amoniak dianggap sebagai } \\
\text { hasil dari nitrifikasi yang mengubah amoniak } \\
\text { menjadi nitrat, yang mengakibatkan } \\
\text { berkurangnya kadar amoniak. }\end{array}$ \\
\hline 6. & $\begin{array}{l}\text { Farahbakhsazad, } \\
\mathrm{N}, \mathrm{dkk}\end{array}$ & 2002 & $\begin{array}{l}\text { Menggunakan tanaman air pada lahan basah } \\
\text { buatan dengan aliran vertikal mampu } \\
\text { mengurangi kadar fosfat sebesar } 93 \% \text {. }\end{array}$ \\
\hline
\end{tabular}

\section{PENUTUP}

Sekitar 60-70\% air yang digunakan sehari-hari dibuang langsung ke lingkungan tanpa adanya pengolahan terlebih dahulu. Pembuangan air limbah domestik secara langsung tanpa adanya pengolahan terlebih dahulu dapat mengakibatkan pencemaran air. Salah satu teknologi untuk mengolah air limbah domestik adalah lahan basah buatan. Dalam lahan basah buatan terdapat dua sistem yang dikembangkan saat ini yaitu Free Water System (FWS) dan Sub-surface Flow System (SSF). Sistem SSF baik untuk diterapkan pada skala 
yang kecil seperti perumahan individual, komunal, taman, sekolah dan fasilitas publik serta area komrsial sedangkan FWS baik untuk diterapkan pada pemukiman skala besar dan sistem industri. Kriteria umum untuk menentukan spesies tumbuhan lahan basah yang cocok untuk pengolahan limbah belum ada, karena sistem yang berbeda memiliki tujuan dan standar yang berbeda. Namun, tumbuhan timbul dan tumbuhan mengapung lebih banyak dipilih untuk digunakan dalam studi lahan basah buatan skala laboratorium.

\section{DAFTAR PUSTAKA}

Abdulgani H, Izzati M, Sudarno. 2013. Pengolahan limbah cair industri kerupuk dengan sistem subsurface flow constructed wetland menggunakan tanaman Typha angustifolia. Prosiding Seminar Nasional Pengelolaan Sumberdaya Alam dan Lingkungan; 2013 Agt 27; Semarang, Indonesia. Semarang (ID): 482-488. ISBN 978602-17001-1-2

Anonim. Peraturan Pemerintah Nomor 82 Tahun 2001 tentang Pengelolaan Kualitas Air dan Pengendalian Pencemaran Air.

Anonim. Peraturan Menteri Lingkungan Hidup dan Kehutanan Nomor 68 Tahun 2016 tentang Baku Mutu Air Limbah Domestik.

Brahmana, S. S., Armaita, S. 2002. Pengurangan Zat Nutrisi Nitrogen dan Fosfat Dalam Air Limbah Dengan Menggunakan Eko-Teknologi-Wetland. JLP. 16(48): 4755.

Crites, R dan Tchobanoglous, G. 1998. Small and Decentralized Wastewater Management Systems Wetlands and Aquatic Treatment. McGraw-gill Book. Co-Singapore.

Dwi Astuti., Ramadhani Yanidar., Yogi Hartanto. 2010. Identifikasi Sumber Dan Beban Pencemar Domestik Di Das Ciliwung Segmen 4 Serta Upaya Penanggulangannya. Indonesian Journal of Urban and Environmental Technology. Vol. 5(4): 117-124. DOI: http://dx.doi.org/10.25105/urbanenvirotech.v5i4.682

Eriksson, E., Auffarth, K., Henze, M., \& Ledin, A. (2002). Characteristics Of Grey Wastewater, Urban Water 4, 85-104.

Farahbakhsazad, N,. G. M. Morrison., and E. S. Filho. 2002. Nutrient Removal in a Vertical Upflow Wetland in Piracicaba, Brasil.AMBIO, A Jurnal of the Human Environment. 29(2): 74-77.

Kent, Donald M. 2001. Applied Wetlands Science and Technology. CRC Press, Boca Raton, Florida.

Metcalf \& Eddy. 2003. Wastewater Engineering Treatment and Reuse. Fourth Edition. MC Graw Hill International, New York.

Meutia, A. A. 2002a. Pengolahan Air Limbah Dengan lahan Basah Buatan. Proseding Seminar Nasional Limnologi. Bogor 22 April 2002. Bogor . Hal.145-153.

Patricia, C. 2018. Kandungan Nitrat dan Fosfat di Sungai Ciliwung. Seminar Nasional Cendekiawan No. 4.

Satmoko, Yudo dan Nusa Idaman. 2018. Status Kualitas Air Sungai Ciliwung di Wilayah DKI Jakarta. Jurnal Teknologi Lingkungan Vol. 19.

Supradata. 2005. Pengolahan Limbah Menggunakan Tanaman Rumput Hias (Cyperus alterifolius) dengan Sistem Aliran Bawah Permukaan. Program Pasca Sarjana Universitas Diponegoro.

Suriawiria, U. 2003. Mikrobiologi Air dan Dasar-Dasar Pengolahan Buangan Secara Biologis. Alumni. Bandung.

Vandith Va, dkk. 2018. The Characteristics Of Domestic Wastewater From Office Buildings In Bandung, West Java, Indonesia. Indonesian Journal of Urban and Environmental Technology. Vol. 1(2): 199-244.

DOI: http://dx.doi.org/10.25105/urbanenvirotech.v1i2.2826 
Vymazal J. 2010. Review of constructed wetlands for wastewater treatment. Water. 2: 530549.

Winursita H, Mangkoedihardjo S. 2013. Penurunan BOD COD pada limbah katering menggunakan pengolahan fisik dan konstruksi subsurface-flow wetland dengan tanaman kana (Canna indica). Jurnal Sains dan Pomits. 2(1): 1-6.

Yazid FR, Syafrudin, Samudro G. 2012. Pengaruh variasi konsentrasi dan debit pada pengolahan air artifisial (campuran greywater dan blackwater) menggunakan reaktor UASB. Jurnal Presipitasi. 9(1):31-40. 